\title{
Estimation of Transformed Continuous Assessment Scores of Rural and Urban Secondary Schools
}

\author{
Adeoye Oluseyi Peter $^{1}$, Babatimehin Temitope ${ }^{2}$, Adamu Chidubem Deborah ${ }^{3}$
}

\section{ARTICLE INFO}

Article History:

Received 26.05.2021

Received in revised form

16.01.2022

Available online

01.07.2022

\begin{abstract}
This study examined the transformed continuous assessment CA scores of Osun State junior secondary schools with a view to providing information on the procedure for transforming CA scores for better comparability of scores among rural and urban secondary schools. The study adopted the ex-post-facto research design. The population for the study comprised all junior secondary school class III students who had CA scores during 2010/2011 session in both rural and urban secondary schools in Osun State. The sample consisted of 1200 students selected using multistage sampling technique. A proforma titled Continuous Assessment Scores Retrieval was used to collect CA scores of the selected students in English Language and Mathematics. Data collected were analyzed using percentages and Pearson's Product moment correlation statistics. The results showed that the transformed CA scores of rural and urban secondary schools were above the mean score in Mathematics (62.70\%) and English Language (66.0\%). The result also showed that there was a significant positive relationship between the transformed CA scores and raw CA scores obtained by students in Mathematics and English Language ( $r=1.00 ; \mathrm{p}<0.05)$. The results further showed that there was a significant difference in the transformed CA scores of rural and urban secondary schools in Mathematics $(t=5.341 ; p<0.05)$ and English Language $(t=4.395 ; p<0.05)$. Finally, it was observed that Osun State Ministry of Education did not use standardized procedures (transformation models) to transform the raw scores submitted by the schools. The study therefore concluded that transformed CA scores of rural and urban secondary schools in Osun State would be comparable if appropriate transformation models were used.
\end{abstract}

CTUARA Journal. All rights reserved Keywords: Continuous assessment, transformed continuous assessment scores, Z-score and T-score.

\section{INTRODUCTION}

A good measurement resulting in accurate data is the foundation of sound decision making. Different authors have defined continuous assessment (CA) differently based on their point of emphasis. Accordingly, Asabe (2007 cited in Abiy, 2013) defines continuous assessment as a classroom process that is integrated with instruction. Similarly, Falayalo (1986) and Juliet (2007), viewing it as an integral part of instruction, considers it as a mechanism whereby the final grading of learners on the cognitive, affective, and psychomotor domains of learning is made (cited in Abiy, 2013). Another definition by Airasian (1991) cited in Adediwura and Adeoye (2016) describes continuous assessment as an assessment approach which should depict the full range of sources and methods teachers use to gather, interpret and synthesize information about learners.

Based on the definitions above, one could infer that Continuous Assessment is an assessment approach which involves the use of a variety of assessment instruments (e.g. tests, projects, assignment, interviews, checklists, rating scale, inventories and anecdotal records), assessing various components of learning, not only the thinking processes (cognitive) but including attitudes, motives, beliefs, behaviours, personality traits (affective) and dexterity (psychomotor).A critical examination of the various views and definitions of continuous assessment presented earlier shows some definite characteristics which educators and evaluators have consistently emphasized. These include that continuous assessment is (i) systematic; (ii) comprehensive; (iii) Cumulative; and (iv) guidance-oriented which helps the teachers to get the requisite information that would guide the future development of the students in term s of subjects to be taken and career options to be pursued. The reasons for using CA in school settings are (i) to gain confidence in what the students know and can do; (ii) to provide all children with opportunities to show what they know; (iii) to promote learning for understanding; (iv) to improve teaching; (v) to help determine what kind of remediation and enrichment activities to provide and to identify which students need assistance; and (vi) to let the students know how well they are progressing in their own learning. In measurement, comparisons are made as part of judgment and 
decision making. For two or more sets of continuous assessment scores to be compared, they must first be transformed into a comparable form (standard score). The most commonly used standard scores are Z scores, T scores, in their own contributions, Adediwura and Adeoye (2016) said standard scores expresses individual raw scores from the distribution mean in terms of the standard deviation of the distribution. In other words, it is a statement of the distance of standard deviation from the mean; Z-score is one of the standard scores thus defined as:

$$
\text { Z-score }=\frac{\text { Raw score }- \text { Mean score }}{\text { Standard deviation }}
$$

A z-score is the most basic standard score. It expresses how far a score is from the mean in terms of standard deviation units. A score that is exactly on the mean corresponds to a $\mathrm{z}$ of 0 . Thus, if the mean of a group of scores is 100 and the standard deviation is 15 , therefore a score that is exactly 1 standard deviation above the mean such as an IQ of 115 corresponds to a $\mathrm{z}$ of +1.00 . A score that is exactly 2 standard deviations above the mean such as an IQ of 130 corresponds to a $\mathrm{z}$ of +2.00 . A score that is exactly 1 standard deviation below the mean such as an IQ of 85 corresponds to a $\mathrm{z}$ of -1.00 . A score that is exactly 2 standard deviations below the mean such as an IQ of 70 corresponds to a $\mathrm{z}$ of -2.00 . If therefore, a set of scores is transformed into a set of $z$ scores, the new distribution would have a mean of 0 and a standard deviation of 1 (Owoyemi, 2000, p.6-7; Bello, 2000, p.9). Afolabi (1999, p.65) argued that converting raw score to T-score is only a form of scaling and incongruity a mark from one scale to another cannot remedial incongruity or morbidity in the original score. He added that if test scores of a class or moderation group in a subject are skewed, converting the raw scores to T-scores will still leave the distribution skewed.

Estimation of standard of continuous assessment scores in rural or urban areas had been one of the major problems being identified by scholars, stakeholders, since inception of 6-3-3-4 system of education. This problem seems to arise as a result of difference in personnel and the practice of continuous assessment. Other problems associated with this include examination malpractices, do-or-die syndrome in examinations, too much of paper qualification, quality of teachers, lack of funding, attitude of students, parents' and teachers' attitudes towards continuous assessment, teachers' integrity, lack of commitment, quality of assessment instruments that vary from staff to staff and from private to public secondary schools even in rural and urban areas. The stated problems have done much damages to the stand ard of Education in the rural areas compared to the urban areas. As a result, most Nigerians believe that the standard of education in Nigeria is falling and that the education provided in the rural areas is very poor when compared to the quality of education received in urban areas. According to these Nigerians, this menace is due to the environment in the rural areas that is not conducive for learning. Our rural areas are laden with poverty, inadequate water supply, poor electricity supply and poor learning environment. It is known that most schools in the rural areas are poorly staffed; it was also asserted by solarin (2001) "that most schools in the rural areas feather their nest including underprivileged schools in the rural areas with no teachers". These factors have direct influence on the teaching and learning of the students. The better performances of urban students when compared to rural students could be as a result of better quality of education given to urban schools and availability of infrastructural facilities like mass media and electronic media. Olanipekun and Okunrotifa (2008) also noted that apart from the inadequate academic background of the students and limited resource for teaching, the quality of teaching offered and assessment process in rural schools is also a major concern researchers need to assess.

In awarding certificates to junior secondary school (JSS) students, continuous assessment and state examination scores are used to arrive at final score in each subject. Studies have shown there could be differences in the school assessment scores, scoring procedures and grading which may pose incomparability of standards and thus give some students undue advantages over others. To harmonize these scores, there should be an acceptable performance standard that should not be viewed as minimum competency but should set high and achievable expectation for every student. Besides, some uniform grades are attached to scores like A, B, C, D, E, F despite the fact that there are no uniform criteria or parameters by which such conclusions are made. Not only that some school registrars seem to manipulate continuous assessment scores with or without the knowledge of the subject teachers before submitting continuous assessment scores to Ministries of Education to be used with Junior Secondary School (JSS) examination for the award of JSS certificate. To facilitate meaningful analysis and interpretation, raw scores are expected to be transformed to other scales. The extent to which Osun State Ministry of Education standardizes these scores is not certain. Thus, there 
is need to ascertain the differences in the transformed continuous assessment scores that are submitted to Ministry: hence this study.

The specific objectives of the study are to: 1. examine the transformed continuous assessment scores of Osun State junior secondary schools; 2. determine the difference in the transformed continuous assessment scores of rural and urban schools in the State and 3. examine the procedures used by Osun State Ministry of Education to transform the raw scores submitted to the Ministry. The following research questions were raised for the study. 1. How far from the mean are the transformed continuous assessment scores of Osun State junior secondary schools? 2. What are the procedures used by Osun State Ministry of Education to transform the raw scores submitted by the schools? The study tested the hypothesis that: there is no significant difference in the transformed continuous assessment scores of rural and urban schools in the State.

\section{METHOD}

This study employed ex-post-facto research design. According to Nworgu (1990, P.82-82), in using ex-post-facto research design, the researcher deals with non-manipulable independent variables. As a result, data are collected after the event or phenomenum under investigation has taken place.

\section{Study Group}

The population for the study consisted of all Junior Secondary School three (JSS 111) students who have continuous assessment scores during 2010/2011 session in rural and urban schools in Osun State. The sample comprised 1200 students with continuous assessment scores in English Language and Mathematics. The population for the study consisted of all Junior Secondary School three (JSS 111) students who have continuous assessment scores during 2010/2011 session in rural and urban schools in Osun State. The sample comprised 1200 students with continuous assessment scores in English Language and Mathematics.

\section{Material}

A Proforma titled "Continuous Assessment Scores Retrieval Format" was used to retrieve English Language and Mathematics continuous assessment scores of 2010/2011 session from Osun State Ministry of Education. The data collected for the research were analyzed using t-test, $z$-score, $t$-score, percentage and Pearson Product Moment Correlation Statistics. Students' examination scores were coded as follows $0-44=$ F (Fail), $45-49=\mathrm{P}$ (Pass), 50 - 59 = C (Merit), 60-69= B (Credit), and $70-100=\mathrm{A}$.

\section{Data Analyses}

The data collected for the research were analyzed using t-test, z-score, $\mathrm{t}$-score, percentage and Pearson Product Moment Correlation Statistics. Students' examination scores were coded as follows $0-44=\mathrm{F}$ (Fail), $45-49=\mathrm{P}$ (Pass), $50-59=\mathrm{C}$ (Merit), $60-69=\mathrm{B}$ (Credit), and $70-100=\mathrm{A}$.

\section{FINDINGS}

Research Question (1): How far from the mean are the transformed continuous assessment scores of Osun State junior secondary schools?

To answer this question, the CA scores of students in Mathematics and English Language were transformed into Z-score the transformed score was then used to determine how far above or below the mean in standard deviation units the raw scores lie. 
Table 1: The distance of the raw from the mean

\begin{tabular}{|c|c|c|c|c|c|}
\hline \multirow[t]{3}{*}{ School Type } & \multicolumn{2}{|c|}{ MATHEMATICS } & \multirow{3}{*}{$\begin{array}{l}\text { Fall Below } \\
\text { Mean by } 1\end{array}$} & \multirow{2}{*}{ Fall Above } & \multirow{3}{*}{$\begin{array}{l}\text { Fall Above } \\
\text { the Mean by } 2 \\
\text { and above SD }\end{array}$} \\
\hline & Fall Below & Fall Below & & & \\
\hline & $\begin{array}{l}\text { the Mean by } 4 \\
\text { SD and Above }\end{array}$ & $\begin{array}{l}\text { the Mean by } 2 \text { to } \\
3 \mathrm{SD}\end{array}$ & & $\begin{array}{l}\text { the Mean by } 1 \\
\text { SD }\end{array}$ & \\
\hline Urban School & 0 & $1(1.8 \%)$ & $309(51.5 \%)$ & $280(46.7 \%)$ & 0 \\
\hline \multirow[t]{3}{*}{ Rural School } & $9(1.5 \%)$ & $21(3.5 \%)$ & $183(30.9 \%)$ & $371(62.7 \%)$ & $8(1.4 \%)$ \\
\hline & & & ENGLISH LANGU & AGE & \\
\hline & $\begin{array}{l}\text { Fall Below the } \\
\text { mean by } 4 \text { SD and } \\
\text { Above }\end{array}$ & $\begin{array}{l}\text { Fall Below the } \\
\text { Mean by } 2 \text { to } 3 \text { SD }\end{array}$ & $\begin{array}{l}\text { Fall Below } \\
\text { the mean by } 1 \mathrm{SD}\end{array}$ & $\begin{array}{l}\text { Fall Above the } \\
\text { Mean by } 1 \mathrm{SD}\end{array}$ & $\begin{array}{l}\text { Fall Above the } \\
\text { Mean by } 2 \text { and above } \\
\text { SD }\end{array}$ \\
\hline Urban School & 0 & $11(1.8 \%)$ & $283(47.2 \%)$ & $306(51.0 \%)$ & 0 \\
\hline Rural School & $9(1.5 \%)$ & $20(3.4 \%)$ & $164(27.7 \%)$ & $390(66.0 \%)$ & $8(1.4 \%)$ \\
\hline
\end{tabular}

Table 1 showed that in Mathematics while $46.7 \%$ and $62.7 \%$ of public and private school students raw scores fall above the mean by one standard deviation, $0 \%$ and $1.5 \%$ of students' scores fall below the mean respectively. Also in the Table, while $47.2 \%$ of public and $27.7 \%$ of private school students scores in English Language fall below the mean by one standard deviation, $51.0 \%$ of public and $66.0 \%$ private school students fall above the mean by one standard deviation. Furthermore, Table 1 showed that in the private schools the scores are widely spread while in the public it is skewed.

Research Question (2): what are the procedures used by Osun State Ministry of Education to transform the raw scores submitted to the Ministry?

To answer the research question, it was observed that the procedure of Osun State Ministry of Education does not use transformation models such as t-score and z-score to transform the raw continuous assessment scores submitted by both private and public secondary schools in the state. The Ministry only assigned certain percentage of sores to Junior Secondary School classes (JSS 1-3), in accordance to Kolawole (2005) who reported that continuous assessment scores should be spread across the three years as follows; $5 \%$ for JSS I, $12.5 \%$ for JSS II, $12.5 \%$ for JSS III and $70 \%$ for the state test.

Hypothesis: The difference in the transformed CA scores of rural and urban schools in the State is not significant.

To test this hypothesis, the sampled students were sorted into rural and urban schools they belong to. The transformed CA scores were then compared using independent $t$-test. The results are as presented in Table 2. 
Table 2: t-test showing the difference in transformed CA scores of private and public schools

\begin{tabular}{|c|c|c|c|c|c|c|}
\hline Mathematics & School Type & $\mathrm{N}$ & Mean & Std. Deviation & $\mathrm{T}$ & $\mathrm{Df}$ \\
\hline \multirow[b]{2}{*}{ Z-Score } & Urban & 600 & -0.152 & .794 & \multirow[b]{2}{*}{5.353} & \multirow[b]{2}{*}{1190} \\
\hline & $\begin{array}{l}\text { School } \\
\text { Rural } \\
\text { School }\end{array}$ & 592 & 0.154 & 1.153 & & \\
\hline \multirow[b]{2}{*}{ T-Score } & $\begin{array}{l}\text { Urban } \\
\text { School }\end{array}$ & 600 & 48.477 & 7.939 & \multirow[b]{2}{*}{5.340} & \multirow[t]{2}{*}{1190} \\
\hline & $\begin{array}{l}\text { Rural } \\
\text { School }\end{array}$ & 592 & 51.543 & 11.528 & & \\
\hline \multirow{2}{*}{$\begin{array}{l}\text { Predictive } \\
\text { True-Score }\end{array}$} & $\begin{array}{l}\text { Urban } \\
\text { School }\end{array}$ & 600 & 64.364 & 18.983 & 5.341 & \multirow[t]{2}{*}{1190} \\
\hline & $\begin{array}{l}\text { Rural } \\
\text { School }\end{array}$ & 592 & 71.694 & 27.565 & 5.341 & \\
\hline \multirow{2}{*}{$\begin{array}{l}\text { Derived True- } \\
\text { Score }\end{array}$} & $\begin{array}{l}\text { Urban } \\
\text { School }\end{array}$ & 600 & 62.620 & 28.076 & \multirow{2}{*}{5.340} & \multirow[t]{2}{*}{1190} \\
\hline & $\begin{array}{l}\text { Rural } \\
\text { School }\end{array}$ & 592 & 73.462 & 40.769 & & \\
\hline \multicolumn{7}{|l|}{$\begin{array}{l}\text { English } \\
\text { Language }\end{array}$} \\
\hline \multirow{2}{*}{ Z-Score } & $\begin{array}{l}\text { Urban } \\
\text { School }\end{array}$ & 600 & -0.125 & 0.812 & \multirow{2}{*}{4.395} & \multirow[t]{2}{*}{1190} \\
\hline & $\begin{array}{l}\text { Rural } \\
\text { School }\end{array}$ & 592 & 0.127 & 1.147 & & \\
\hline \multirow{2}{*}{ T-Score } & $\begin{array}{l}\text { Urban } \\
\text { School }\end{array}$ & 600 & 48.745 & 8.121 & \multirow{2}{*}{4.395} & \multirow[t]{2}{*}{1190} \\
\hline & $\begin{array}{l}\text { Rural } \\
\text { School }\end{array}$ & 592 & 51.272 & 11.465 & & \\
\hline \multirow{2}{*}{$\begin{array}{l}\text { Predictive } \\
\text { True Score }\end{array}$} & $\begin{array}{l}\text { Urban } \\
\text { School }\end{array}$ & 600 & 64.832 & 19.575 & \multirow{2}{*}{4.395} & \multirow[t]{2}{*}{1190} \\
\hline & $\begin{array}{l}\text { Rural } \\
\text { School }\end{array}$ & 592 & 70.922 & 27.634 & & \\
\hline \multirow{2}{*}{$\begin{array}{l}\text { Derived True } \\
\text { Score }\end{array}$} & $\begin{array}{l}\text { Urban } \\
\text { School }\end{array}$ & 600 & 63.385 & 28.937 & \multirow{2}{*}{4.395} & \multirow[t]{2}{*}{1190} \\
\hline & $\begin{array}{l}\text { Rural } \\
\text { School }\end{array}$ & 592 & 72.388 & 40.851 & & \\
\hline
\end{tabular}

The result as presented in Table 2 showed that the difference in the transformed CA of rural and urban school students for both Mathematics and English Language is significant at 0.05 level significance.

\section{DISCUSSION}

Estimation of transformed continuous assessmentscores of rural and urban secondary school in Osun state is to examine the transformation of continuous assessment scores of rural and urban secondary schools in Osun state. The research question one determined how far from the mean the transformed continuous assessment scores of Osun state junior secondary schools. The result indicated that the transformed continuous assessment scores of rural and urban secondary schools were above the mean score in Mathematics $(62.70 \%)$ and English Language $(66.00 \%)$, it showed the results are comparable in both subjects. The research question two which examined the procedures Osun state ministry of Education used for the transformation of the raw scores submitted to the ministry revealed that the Osun state Ministry of Education does not use transformation models such as t-score and z-score to transform the raw continuous assessment scores submitted by both rural and urban secondary schools in the state. The Ministry only assigned certain percentage of sores to junior secondary classes (JSS 1-3), the percentage as follows: $5 \%$ for JSS I, $12.5 \%$ for JSS II, and $12.5 \%$ for JSS III. The hypothesis determined the difference in the transformed continuous assessment scores of rural and urban 
secondary schools in Osun State. The result indicated that there was a significant difference in the transformed continuous assessment scores in the selected subjects (English Language and Mathematics) in Osun State.

The result also showed that when Z-score and T-score were used for the transformation of continuous assessment scores for the selected school subjects across the state, there was no significant difference. This may be as a result of one being the transformation of the other, that is, T-score is a linear transformation of Z-score. When a score is skewed and transformed with the use of Z-score and T-score, it remains skewed. The finding supports the study of Afolabi (1999, p.66-67) who maintained that converting raw score to T-score is only a form of scaling and converting a mark from one scale to another cannot remedy incongruity or morbidity in the original score. While in the study of Ayodele (2010) he recommended the use of true score for the transformation of continuous assessment scores in English Language and Mathematics for comparability of standard. The result further indicated that significant differences did exist in transformed continuous assessmentscores in the State.

The result showed there was a significant difference among selected school subjects when Continuous Assessment scores were transformed with the use of True score, Predictive true score and Derived true score while that of Z-score and T-score were not significant. Alonge (2004, p.107-108) said, before comparing children's performance across subjects and across schools, there are need to process their raw scores in each subject. It has been a tradition/phenomena for parents/guardians to compare scores of their children/wards from various subjects and punish/beat/deny their children for getting low scores in certain subjects without considering some parameters like the contents, difficulty level and discriminating power of the items, mean score, etc., because they lack the knowledge of test score types and interpretations.

The study therefore concluded that transformed continuous assessment scores of rural and urban schools in Osun State are comparable if transformation models are used to transform the raw scores submitted by secondary schools to the Ministry. Continuous assessment scores for the selected subjects were slightly comparable. Also, schools' continuous assessment scores were heterogeneous with homogeneous subgroups. The awards of continuous assessment scores differ from school to school both in rural and urban secondary schools and among Local Government Areas in Osun State. Also, Osun State Ministry of Education does not use transformation models to transform continuous assessment submitted by schools.

Based on the findings, the following suggestions were made: Efforts should be made intensified by the teachers to generate valid and reliable continuous assessment scores. Subject teachers should meet regularly on the techniques/methods to use on construction of continuous assessment instruments for uniformity on the basic schools both rural and urban schools, Local Government Areas and even at state levels for homogeneity. Ministries of Education (continuous assessment units) and Examination bodies should as a matter of urgency introduce the use of True score for the transformation of continuous assessment scores sent to them.

\section{References}

Abiy Y. (2013). High school English teachers' and students' perceptions, attitudes and actual practices of continuous assessment. Academic Journals,8(16), 1489-1498.

Airasian, P. W. (1991). Classroom assessment. New York: McGraw-Hill.

Adeoye, O. P. (2016). Comparative analysis of transformed continuous assessment score of secondary Schools in Osun State. Unpublished Master's degree thesis, Obafemi Awolowo University, Ile-Ife.

Afolabi, E. R. I. (1999). Six Honest men for continuous assessment, evaluating the equation of achievement scores in Nigeria secondary schools. Journal of Behavioural Research, 2(1), 62-66.

Alonge, M. F. (2004). Examination bodies and the development of modern technique of assessment and examination in Nigeria. Journal of Counselling and Applied Psychology,1(1), 97-108.

Ayodele, C. S. (2010). Comparability of standard of continuous assessment in secondary schools in Nigeria. Unpublished $\mathrm{PhD}$ thesis, University of Ado-Ekiti, Ekiti.

Aytaged, S. (2013). A comparative study on the practice of continuous assessment between Addis Ababa and Unity universities. Global Journal of Comparative Education,1(1), 50-58.

Bello, G. (2000). Scientific development and the challenge of science education. Nigerian Journal of Educational Researchers and Evaluators, 2(2), 10-11.

Birhanu, M. (2013). Continuous assessment issues and practices in secondary schools of Oromia Regional State, Ethiopia: The "Big Picture" of assessment mechanism. Available online: http://www.palgojournals.org

Bandele, S. O. (1993). Patterns of relationship between internal and external assessment of some junior secondary subjects in Nigeria. Journal of Educational Leadership, 6(1), 50-54. 
Desalegn C. (2014). Practices of assessing graduate students' learning outcomes in selected Ethiopian higher education institutions. Journal of International Cooperation in Education, 16(2) 157-180.

Falayajo, W. (1986). Philosophy and theory of continuous assessment. A paper presented at a workshop for Inspectors of Education in Ondo State, Nigeria.

Federal Ministry of Education, Science and Technology (1985). A handbook on continuous assessment. Ibadan: Heinemann Educational Books.

Kolawole, E. B. (2005). Tests and measurement. Ado-Ekiti: Yemi Printing Services.

Nworgu, B. G. (1990). Educational research: Basic issues and methodology. University Trust Publishers: Nsukka Enugu.

Olanipekun I. O. \& Okunrotifa M. I. (2008). The quality of teaching on educational performance. Aseminapaper presented at the 5th National Conference on Examination,Imo state.

Obioma G. (2008). Public Examinations as predictors of university students' academic achievement. Nigeria Educational Research and Development Council (NERDC), Abuja Nigeria.

Oluwatayo, J. A. (2003). Mode of entry and performance of Nigerian universities undergraduates in science courses. Ekiti, 63(3) 147-165.

Owoyemi, N. (2000). Moderation and standardization of continuous and terminal assessmentscores in junior secondary school certificate examination and primary school leaving certificate assessment. Paper Delivered at the Senior Staff Seminar, Ministry of Education, Ado- Ekiti, pp: 2-9.

Universal Basic Education Commission (2001). Report of National Assessment 2001 of the Universal Basic Education (UBE) Programme. Abuja. 